\title{
Stereoselective synthesis of cis-fused hexahydro-isoindolones
}

\author{
Susanne Rehn, Armin R. Ofial, Kurt Polborn, and Herbert Mayr* \\ Department Chemie der Ludwig-Maximilians-Universität München, \\ Butenandtstrasse 5-13 (Haus F), D-81377 München, Germany \\ E-mail: Herbert.Mayr@,cup.uni-muenchen.de
}

Dedicated to Professor Mieczysław Mąkosza on the occasion of his $70^{\text {th }}$ birthday

(received 14 Nov 03; accepted 12 Jan 04; published on the web 30 Jan 04)

\begin{abstract}
Allylamines, readily accessible by ene reactions of $N, N$-dibenzyliminium pentachlorostannates with 1,3-enynes, undergo domino reactions with maleic anhydride or maleic imide to give cisfused hexahydroisoindolones, which were characterized by x-ray analysis.
\end{abstract}

Keywords: Diels-Alder reactions, isoindolones, lactams, stereoselectivity, x-ray analysis

\section{Introduction}

The reactions of iminium ions with alkynes provide a general access to allylamines. ${ }^{1-3} \mathrm{~N}, \mathrm{~N}-$ dibenzylmethyleneammonium ions $\mathbf{1}$, for example, undergo ene reactions with inverse electron demand with mono- and disubstituted acetylenes $\mathbf{2}$ to yield the iminium ions $\mathbf{3}$ which hydrolyze with formation of the N-benzyl protected allylamines $\mathbf{4}$ (Scheme 1$)^{2}{ }^{2}$

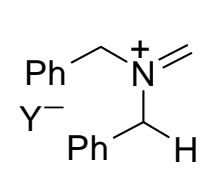

1

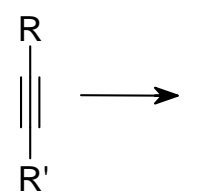

2

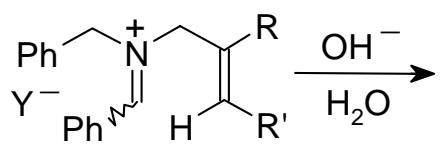

3<smiles>[R]C=C([R])CNCc1ccccc1</smiles>

4

\section{Scheme 1}

Though ene reactions of iminium ions with CC-double bonds have also been reported, ${ }^{4,5}$ CCtriple bonds are more reactive with the consequence that conjugated enynes $\mathbf{5}$ can selectively be converted into the corresponding dienylamines 6 (Equation 1). ${ }^{2}$ 


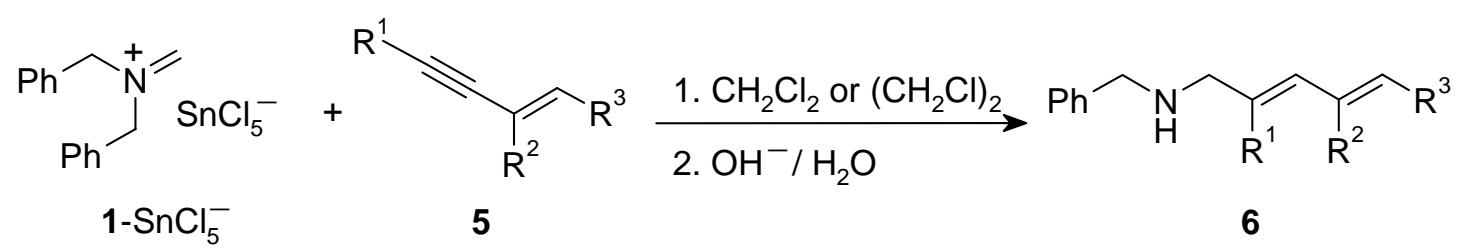

We now report that the reactions of the dienylamines $\mathbf{6}$, thus readily available, with maleic anhydride and maleic imide provide a straightforward access to partially hydrogenated N-benzyl3-oxoisoindolone-4-carboxylic acid derivatives 7,,7 a building block of a variety of natural products $^{8,9}$ and biologically active compounds. ${ }^{10-12}$

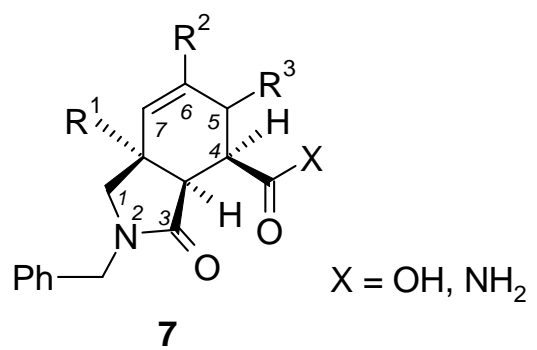

\section{Results}

Heating equimolar amounts of the 2,4-dienylamine 6a with maleic anhydride or maleic imide in toluene gave rise to the formation of the bicyclic lactams $\mathbf{r a c} \mathbf{- 8}$ and $\mathbf{r a c} \mathbf{- 9}$, respectively. The moderate yields of both reactions given in Scheme 2 were mainly caused by the consecutive crystallization procedure, and no attempt of optimization was undertaken.

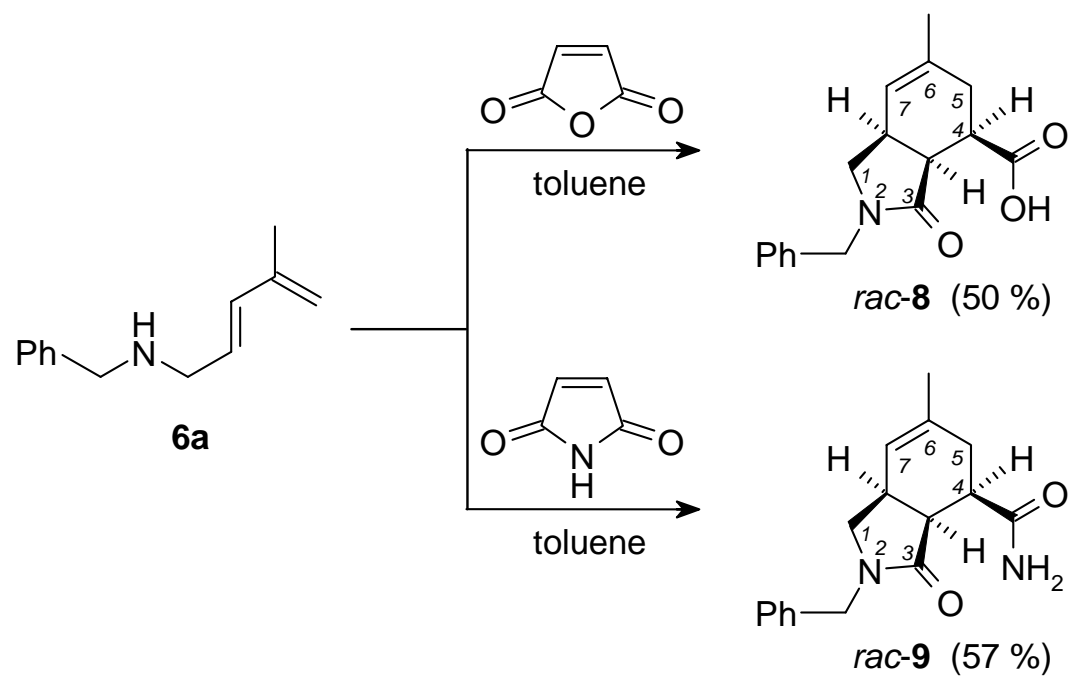

\section{Scheme 2}


Vicinal coupling constants of $J_{3 \mathrm{a}, 7 \mathrm{a}}=6.8 \mathrm{~Hz}$ and $6.6 \mathrm{~Hz}$ were observed in the ${ }^{1} \mathrm{H}$ NMR spectra for the lactams $\mathbf{8}$ and $\mathbf{9}$, respectively, and additional 2D NMR experiments indicated the formation of $c i s$-fused ring systems. In order to unequivocally establish the molecular structures of $\mathbf{8}$ and 9, crystals suitable for X-ray structure analysis were grown from ethyl acetate/petroleum ether mixtures. The ZORTEP plots in Figures 1 and 2 clearly demonstrate the cis-ring junction in both lactams $r a c-8$ and $r a c-9$.

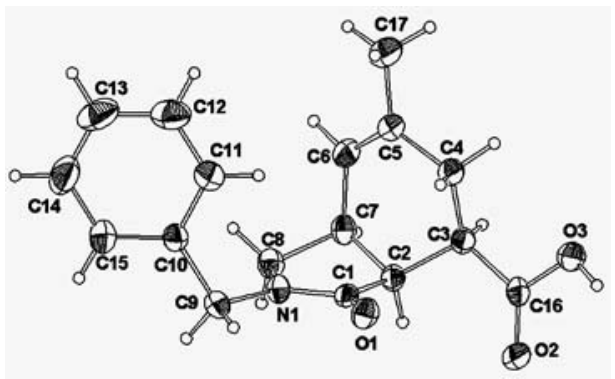

Figure 1. ZORTEP plot of $\mathbf{8}$.

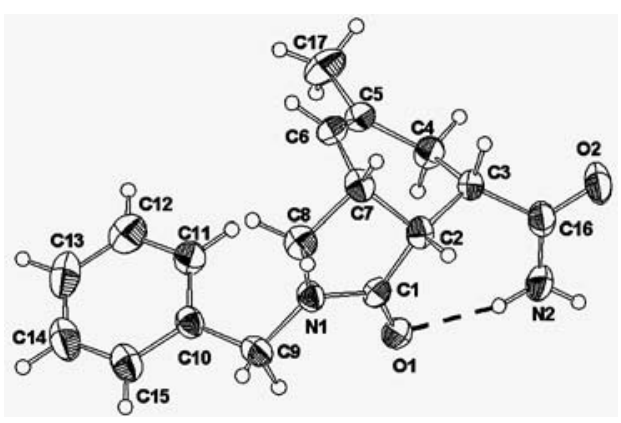

Figure 2. ZORTEP plot of $\mathbf{9}$. The intramolecular hydrogen bond between N2 and O1 is shown by a dashed line.

The crystal structure of 9 reveals the presence of intermolecular hydrogen bonds between the free amido groups with O2-N2A distances of 288.9 pm. Further, a stronger intramolecular hydrogen bond between N2 and O1 (279.4 pm) can be found (Figure 2) which also persists in $\mathrm{CDCl}_{3}$ solution and gives rise to separate NMR resonances at $\delta 5.64$ and 9.10 for the protons of the $-\mathrm{NH}_{2}$ group.

In the crystal structure of the analogous lactam 8 that carries a -COOH group, intramolecular hydrogen bonds could not be observed. However, intermolecular $\mathrm{O}-\mathrm{H}$ - O hydrogen bonds also play an important role in the solid state of $\mathbf{8}$ and induce the pairing of enantiomers as shown in Figure 3. 


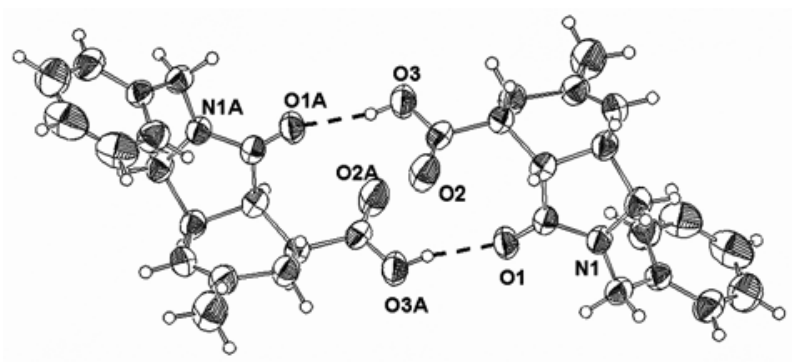

Figure 3. Intermolecular hydrogen bonding pattern in the crystals of racemic $\mathbf{8}(d(\mathrm{O} 1-\mathrm{O} 3 \mathrm{~A})=$ $265.8 \mathrm{pm})$.

In an analogous reaction of $\mathbf{6 b}$ with maleic anhydride, the silylated bicyclic lactam $\mathrm{rac}-\mathbf{1 0}$ was obtained (Scheme 3). Though the quality of the crystals was not high enough for an X-ray analysis, the cis-fusion of the carbon skeleton could clearly be derived from the NOESY spectrum which showed signal enhancements for 1-H $(\delta 3.42)$, 3a-H, 4-H, and 7-H when the protons of the trimethylsilyl group were irradiated.

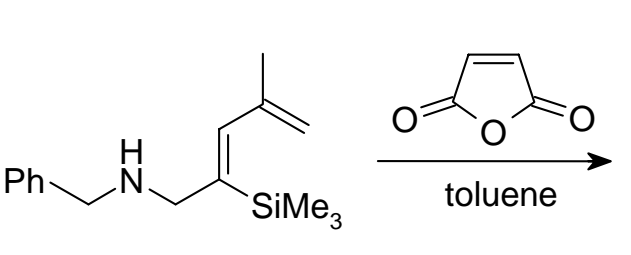

$6 b$

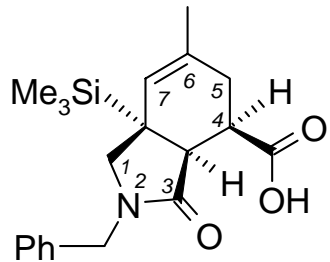

rac-10 (65\%)

\section{Scheme 3}

The reactions of the dienylamine $\mathbf{6 c}$ with maleic anhydride and maleic imide yielded the tricyclic lactams $r a c-11$ and $r a c-12$, respectively (Scheme 4). The cis-annelation of the lactam and the cyclohexene ring was already indicated by the small vicinal coupling constant of $J_{3 \mathrm{a}, 9 \mathrm{a}}=$ 6.3 Hz that was found in the ${ }^{1} \mathrm{H}$ NMR spectrum of 12. Furthermore, the X-ray analysis of crystals of $\mathbf{1 2}$ that precipitated from a ethyl acetate/petrolem ether mixture proved that all protons of the central six-membered ring are located at the same face which gives rise to a bowl-shaped molecular structure (Figure 4). This finding is in accord with the observations by Crisp and Gebauer $^{7}$ who reported analogous reactions of chiral dienylamines with maleic anhydride. 


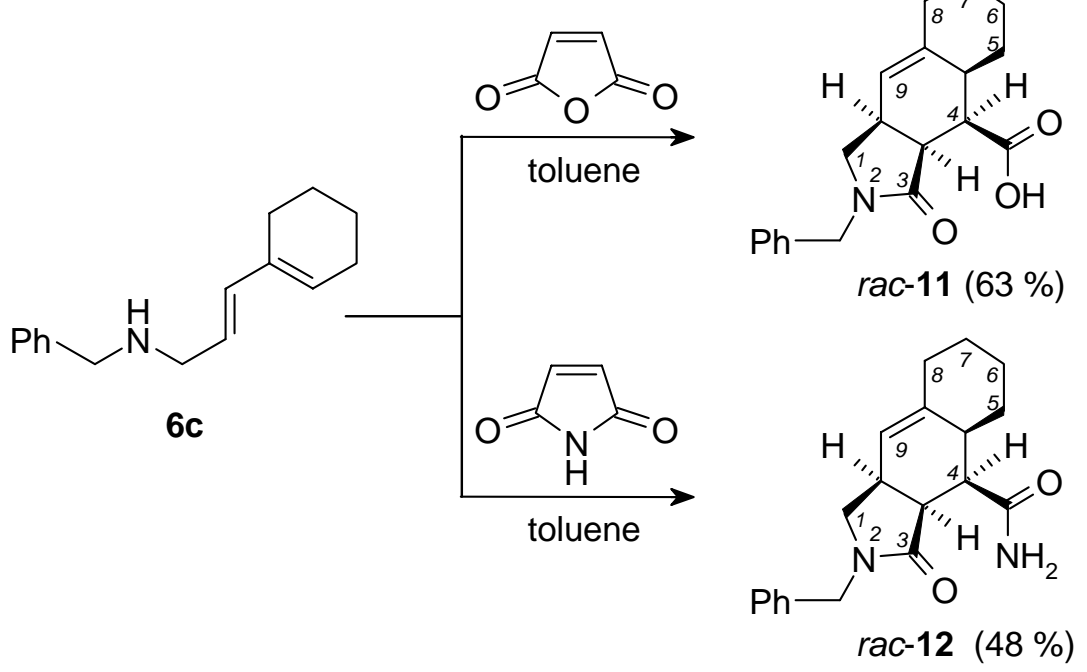

\section{Scheme 4}

Similar to the molecular structure of 9, the interatomic distance of $276.2 \mathrm{pm}$ indicates the presence of an intramolecular hydrogen bond between the lactam oxygen $\mathrm{O} 1$ and the amido nitrogen $\mathrm{N} 2$ of 12. Furthermore, each of the $-\mathrm{CONH}_{2}$ groups is involved in a weaker intermolecular hydrogen bond (296.1 pm) between N2 and O2A. In agreement with the properties in the solid state, the ${ }^{1} \mathrm{H}$ NMR signals of the two protons bound to $\mathrm{N} 2$ are observed at chemical shifts that differ by $4.10 \mathrm{ppm}$.

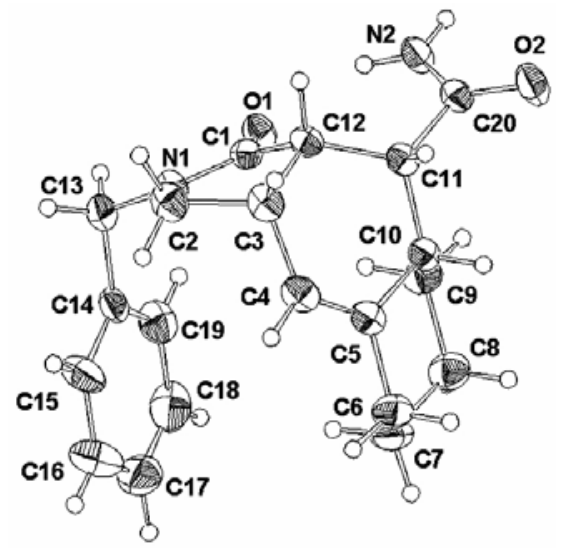

Figure 4. ZORTEP plot of $12(d(\mathrm{O} 1-\mathrm{N} 2)=276.2 \mathrm{pm})$. 


\section{Discussion}

The isoindolone derivatives $\mathbf{8}-\mathbf{1 2}$ which could be isolated in moderate yields from the reactions of maleic acid or maleic imine with dienylamines uniformly showed cis-annelation of the lactam ring to the adjacent cyclohexenyl ring though the presence of smaller amounts of trans-annelated products in the crude reaction products cannot be excluded. This observation contrasts the report by Mellor and Wagland ${ }^{6}$ who described that the reaction of maleic anhydride with N-benzylhexa-2,4-dienylamine in toluene gave rise to the formation of a trans-fused hexahydroisoindolone (yield: $82 \%$ ) with a coupling constant of $J_{3 \mathrm{a}, 7 \mathrm{a}}=12.5 \mathrm{~Hz}$.

Because Diels-Alder reactions generally show preference for the formation of endoproducts, ${ }^{13}$ the observed cis-fusion of the bicyclic ring system in $\mathbf{8}-\mathbf{1 2}$ can be rationalized by the two different reaction paths A and B in Scheme 5.

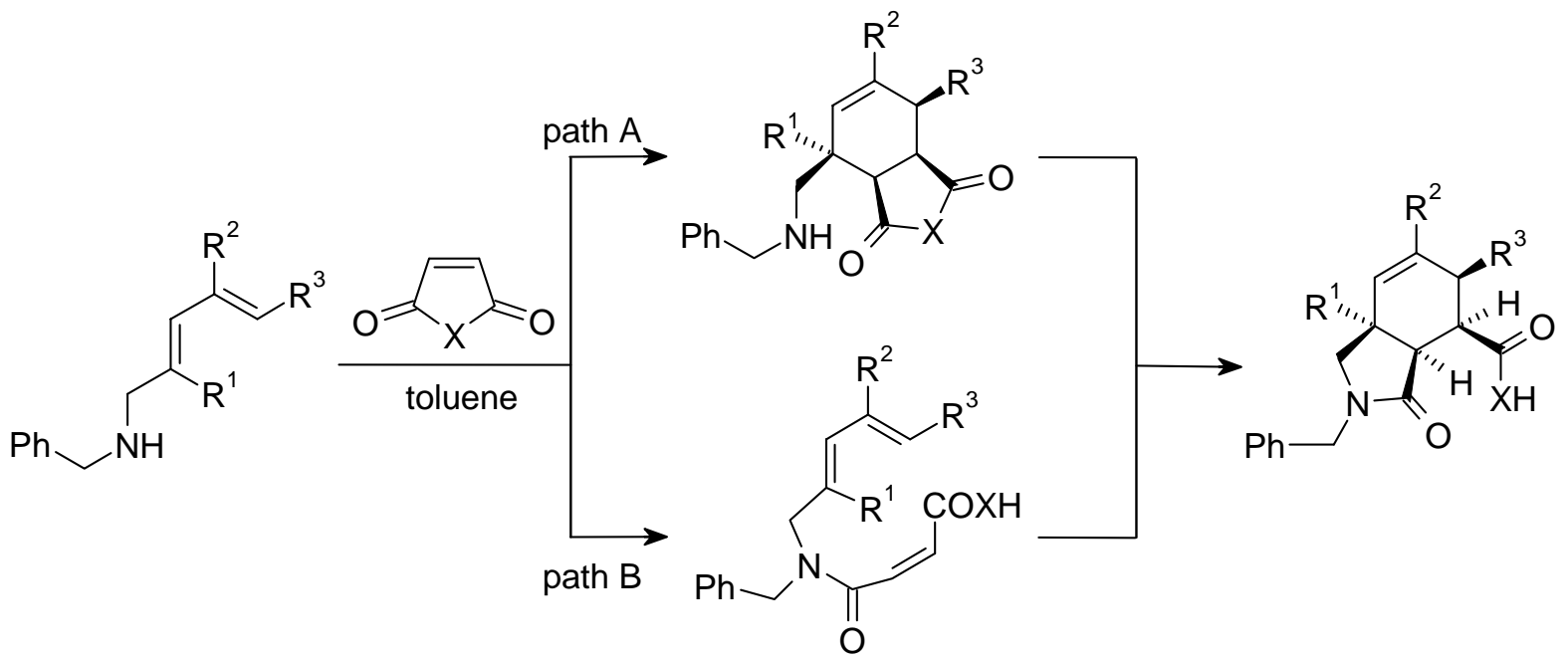

\section{Scheme 5}

Crisp and Gebauer demonstrated that Cbz-protected allylamines are not capable of attacking maleic anhydride. Therefore, they concluded that in the reactions of Cbz-protected dienylamines with maleic anhydride, the intermolecular Diels-Alder reaction precedes the $\mathrm{N}$-attack on the anhydride, as suggested by path A in Scheme $5 .^{\text {7a }}$

The situation is different for the N-benzyl substituted allylamines used in this work: When a solution of equimolar amounts of dibenzylamine (14) and maleic anhydride in $d_{8}$-toluene was kept at $20{ }^{\circ} \mathrm{C}$ for 15 min and analyzed by ${ }^{1} \mathrm{H}$ NMR, ${ }^{14}$ quantitative conversion into amide $\mathbf{1 5}$ was observed (Scheme 6). 


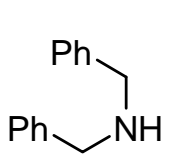

14

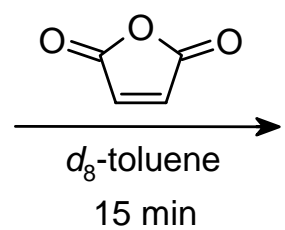

$15 \min$

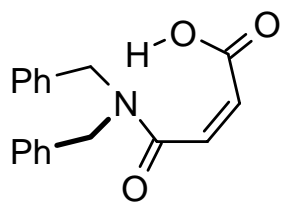

15

\section{Scheme 6}

As the corresponding intermolecular Diels-Alder reactions are considerably slower (4 $\mathrm{d}$ at $25^{\circ} \mathrm{C}, 12 \mathrm{~h}$ at $\left.40^{\circ} \mathrm{C}\right)^{7 \mathrm{a}}$ we can rule out path A as a major pathway in the domino reactions ${ }^{15}$ of the N-benzyl-substituted dienylamines with maleic anhydride. Because of the lower electrophilicity of maleic imide, the sequence of the two reaction steps may be different from the reactions with maleic anhydride.

\section{Experimental Section}

General Procedures. Dienylamines 6a-c were prepared as described before. ${ }^{2}$ Maleic anhydride (>99\%, Fluka) and maleic imide (>98\%, Merck) were used as purchased.

${ }^{1} \mathrm{H}$ NMR spectra $(300,400$, or $600 \mathrm{MHz})$ and ${ }^{13} \mathrm{C}$ NMR spectra $(75.5$ or $100.6 \mathrm{MHz}$ ) refer to $\mathrm{CDCl}_{3}\left(\delta_{\mathrm{H}} 7.24 \mathrm{ppm}, \delta_{\mathrm{C}} 77.00 \mathrm{ppm}\right)$. DEPT experiments were used to obtain information about the multiplicity of the ${ }^{13} \mathrm{C}$ resonances. Mass spectra $(70 \mathrm{eV}, \mathrm{EI})$ were obtained on a Finnigan MAT 95 Q.

2-Benzyl-6-methyl-3-oxo-2,3,3a,4,5,7a-hexahydro-1H-isoindole-4-carboxylic acid (8). A solution of $\mathbf{6 a}$ (2.62 g, $14.0 \mathrm{mmol})$ and maleic anhydride (1.25 g, $12.7 \mathrm{mmol})$ in toluene (20 mL) was heated to reflux for $4 \mathrm{~h}$. Removal of the solvent in vacuo yielded $3.78 \mathrm{~g}$ of a red viscous liquid oil. The crude product crystallized from a mixture of ethyl acetate and petroleum ether $(1 / 1, \mathrm{v} / \mathrm{v})$ to give $8(1.82 \mathrm{~g}, 50 \%)$ as colorless crystals; mp $161-163{ }^{\circ} \mathrm{C}$.

NMR data: $\delta_{\mathrm{H}}\left(\mathrm{CDCl}_{3}, 300 \mathrm{MHz}\right) 1.71\left(\mathrm{~s}, 3 \mathrm{H}, \mathrm{CH}_{3}\right), 2.17-2.41$ (m, $\left.2 \mathrm{H}, 5-\mathrm{H}_{2}\right), 2.84-2.95$ (m, 2 H, 4-H and 7a-H), 2.91 (d, ${ }^{2} J=10.1,1 \mathrm{H}, 1 / 2 \times 1-\mathrm{H}_{2}$ ), 3.32 (dd, $\left.J=6.8, J=2.9,1 \mathrm{H}, 3 \mathrm{a}-\mathrm{H}\right), 3.53$ (dd, $\left.{ }^{2} J=10.0, J=6.2,1 \mathrm{H}, 1 / 2 \times 1-\mathrm{H}_{2}\right), 4.31,4.59$ ( $2 \mathrm{~d}$, each $\left.{ }^{2} J=14.9,2 \times 1 \mathrm{H}, \mathrm{PhCH}_{2}\right), 5.12$ (s, $1 \mathrm{H}, 7-\mathrm{H}), 7.11-7.33$ (m, $5 \mathrm{H}, \mathrm{Ph}), 12.15$ (br s, COOH). $\delta_{\mathrm{C}}\left(\mathrm{CDCl}_{3}, 75.5 \mathrm{MHz}\right) 23.4\left(\mathrm{q}, \mathrm{CH}_{3}\right)$, 29.1 (t, C-5), 34.1 (d, C-7a), 41.3, 41.4 (2 d, C-3a and C-4), 46.6 (t, $\mathrm{PhCH}_{2}$ ), 52.0 (t, C-1), 121.0 (d, C-7), 127.67, 127.73, 128.6 (3 d, Ph), 134.9, 136.5 (2 s, Ph and C-6), 175.2, 175.4 (2 s, $\mathrm{COOH}$ and CO). Signal assignments are based on ${ }^{1} \mathrm{H},{ }^{13} \mathrm{C}-\mathrm{COSY}$ and NOESY experiments. Anal. Calcd. for $\mathrm{C}_{17} \mathrm{H}_{19} \mathrm{NO}_{3}$ (285.34): C, 71.56; H, 6.71; N, 4.91. Found: C, 71.46; H, 6.77; N, 4.94.

2-Benzyl-6-methyl-3-oxo-2,3,3a,4,5,7a-hexahydro-1H-isoindol-4-carboxamide (9). A solution of $\mathbf{6 a}$ (2.62 g, $14.0 \mathrm{mmol}$ ) and maleic imide (1.36 g, $14.0 \mathrm{mmol})$ in toluene (20 mL) was heated to reflux for $4 \mathrm{~h}$. Removal of the solvent in vacuo yielded $3.98 \mathrm{~g}$ of a red viscous oil. The 
crude product crystallized from a mixture of ethyl acetate and petroleum ether $(1 / 1, \mathrm{v} / \mathrm{v})$ to give 9 ( $2.27 \mathrm{~g}, 57 \%$ ) as colorless crystals; mp $131-134^{\circ} \mathrm{C}$.

NMR data: $\delta_{\mathrm{H}}\left(\mathrm{CDCl}_{3}, 400 \mathrm{MHz}\right) 1.72\left(\mathrm{~s}, 3 \mathrm{H}, \mathrm{CH}_{3}\right), 2.23-2.41\left(\mathrm{~m}, 2 \mathrm{H}, 5-\mathrm{H}_{2}\right), 2.69-2.74(\mathrm{~m}, 1$ H, 4-H), 2.87 (d, ${ }^{2} J=9.8,1 \mathrm{H}, 1 / 2 \times 1-\mathrm{H}_{2}$ ), 2.91 (br s, $1 \mathrm{H}, 7 \mathrm{a}-\mathrm{H}$ ), 3.17 (br d, $J=6.6 \mathrm{~Hz}, 1 \mathrm{H}, 3 \mathrm{a}-$ $\mathrm{H}), 3.46$ (dd, $\left.{ }^{2} J=9.6, J=6.1,1 \mathrm{H}, 1 / 2 \times 1-\mathrm{H}_{2}\right), 4.29,4.56\left(2 \mathrm{~d}\right.$, each ${ }^{2} J=14.9,2 \times 1 \mathrm{H}, \mathrm{PhCH}_{2}$ ), 5.10 (s, $1 \mathrm{H}, 7-\mathrm{H}), 5.64$ (br, $\left.1 \mathrm{H}, 1 / 2 \times \mathrm{CONH}_{2}\right), 7.12-7.33(\mathrm{~m}, 5 \mathrm{H}, \mathrm{Ph}), 9.10$ (br, $1 \mathrm{H}, 1 / 2 \times$ $\left.\mathrm{CONH}_{2}\right) . \delta_{\mathrm{C}}\left(\mathrm{CDCl}_{3}, 100.6 \mathrm{MHz}\right) 23.3\left(\mathrm{q}, \mathrm{CH}_{3}\right), 30.7$ (t, C-5), 35.3 (d, C-7a), 42.1 (d, C-3a), 43.6 (d, C-4), 46.5 (t, $\mathrm{PhCH}_{2}$ ), 51.3 (t, C-1), 121.5 (d, C-7), 127.6, 127.7, 128.5 (3 d, Ph), 135.6, 137.4 ( $2 \mathrm{~s}$, Ph and C-6), 174.2, 177.0 (2 s, $\mathrm{CONH}_{2}$ and $\mathrm{CO}$ ). Signal assignments are based on ${ }^{1} \mathrm{H},{ }^{1} \mathrm{H}$-COSY and HETCOR experiments. Anal. Calcd. for $\mathrm{C}_{17} \mathrm{H}_{20} \mathrm{~N}_{2} \mathrm{O}_{2}$ (284.36): C, 71.81; H, 7.09; N, 9.85. Found: C, 71.48; H, 6.98; N, 9.72.

\section{2-Benzyl-6-methyl-3-oxo-7a-trimethylsilyl-2,3,3a,4,5,7a-hexahydro-1H-isoindol-4-carboxy-}

lic acid (10). A solution of $\mathbf{6 b}(3.88 \mathrm{~g}, 15.0 \mathrm{mmol})$ and maleic anhydride $(1.33 \mathrm{~g}, 13.6 \mathrm{mmol})$ in toluene $(20 \mathrm{~mL}$ ) was heated to reflux for $4 \mathrm{~h}$. Removal of the solvent in vacuo yielded $3.55 \mathrm{~g}$ of a red viscous oil. The crude product crystallized from a mixture of ethyl acetate and petroleum ether $(1 / 1, \mathrm{v} / \mathrm{v})$ to give $\mathbf{1 0}(3.17 \mathrm{~g}, 65 \%)$ as colorless crystals; mp $153-155^{\circ} \mathrm{C}$.

NMR data: $\delta_{\mathrm{H}}\left(\mathrm{CDCl}_{3}, 300 \mathrm{MHz}\right) 0.06$ (s, $\left.9 \mathrm{H}, \mathrm{SiMe}_{3}\right), 1.75$ (s, $\left.3 \mathrm{H}, \mathrm{CH}_{3}\right), 2.26-2.47$ (m, $2 \mathrm{H}, 5-$ $\mathrm{H}_{2}$ ), 2.85-2.91 (m, $\left.1 \mathrm{H}, 4-\mathrm{H}\right), 2.89$ (d, $\left.{ }^{2} J=9.9,1 \mathrm{H}, 1 / 2 \times 1-\mathrm{H}_{2}\right), 3.20$ (d, $\left.J=2.5,1 \mathrm{H}, 3 \mathrm{a}-\mathrm{H}\right), 3.42$ (d, $\left.{ }^{2} J=9.7,1 \mathrm{H}, 1 / 2 \times 1-\mathrm{H}_{2}\right), 4.18,4.75\left(2 \mathrm{~d}\right.$, each $\left.{ }^{2} J=15,2 \times 1 \mathrm{H}, \mathrm{PhCH}{ }_{2}\right), 5.04(\mathrm{~s}, 1 \mathrm{H}, 7-\mathrm{H})$, 7.11-7.43 (m, $5 \mathrm{H}, \mathrm{Ph}$ ), 13.2 (br s, $1 \mathrm{H}, \mathrm{COOH}) . \delta_{\mathrm{C}}\left(\mathrm{CDCl}_{3}, 75.5 \mathrm{MHz}\right)-3.5$ (q, $\left.\mathrm{SiMe}_{3}\right), 23.5(\mathrm{q}$, $\mathrm{CH}_{3}$ ), 29.4 (t, C-5), 33.6 (s, C-7a), 41.3 (d, C-4), 43.4 (d, C-3a), 46.6 (t, $\mathrm{PhCH}_{2}$ ), 54.3 (t, C-1), 122.9 (d, C-7), 127.5, 127.7, 128.6 (3 d, Ph), 134.3, 134.9 (2 s, Ph and C-6), 175.42, 176.2 (2 s, $\mathrm{COOH}$ and CO). Signal assignments are based on ${ }^{1} \mathrm{H},{ }^{13} \mathrm{C}-\mathrm{COSY}$ and NOESY experiments. Anal. Calcd. for $\mathrm{C}_{20} \mathrm{H}_{27} \mathrm{NO}_{3} \mathrm{Si}$ (357.52): C, 67.19; H, 7.61; N, 3.92. Found: C, 67.22; H, 7.67; N, 3.91.

\section{2-Benzyl-3-oxo-2,3,3a,4,4a,5,6,7,8,9a-octahydro-1H-benzo[f]isoindol-4-carboxylic acid}

(11). A solution of $\mathbf{6 c}(1.05 \mathrm{~g}, 4.62 \mathrm{mmol})$ and maleic anhydride $(0.41 \mathrm{~g}, 4.2 \mathrm{mmol})$ in toluene $(10 \mathrm{~mL})$ was heated to reflux for $90 \mathrm{~min}$. Removal of the solvent in vacuo yielded $1.78 \mathrm{~g}$ of a red viscous oil. The crude product crystallized from a mixture of ethyl acetate and petroleum ether $(1 / 1, \mathrm{v} / \mathrm{v})$ to give 11 (948 $\mathrm{mg}, 63 \%)$ as colorless crystals; mp $168-170{ }^{\circ} \mathrm{C}$.

NMR data: $\delta_{\mathrm{H}}\left(\mathrm{CDCl}_{3}, 400 \mathrm{MHz}\right) 1.18-1.25\left(\mathrm{~m}, 1 \mathrm{H}, 1 / 2 \times 7-\mathrm{H}_{2}\right), 1.37-1.45\left(\mathrm{~m}, 2 \mathrm{H}, 1 / 2 \times 5-\mathrm{H}_{2}\right.$ and $\left.1 / 2 \times 6-\mathrm{H}_{2}\right), 1.83-2.04\left(\mathrm{~m}, 4 \mathrm{H}, 1 / 2 \times 5-\mathrm{H}_{2}, 1 / 2 \times 6-\mathrm{H}_{2}, 1 / 2 \times 7-\mathrm{H}_{2}\right.$ and $\left.1 / 2 \times 8-\mathrm{H}_{2}\right), 2.17-2.22(\mathrm{~m}$, $1 \mathrm{H}, 1 / 2 \times 8-\mathrm{H}_{2}$ ), 2.49-2.52 (m, $\left.1 \mathrm{H}, 4 \mathrm{a}-\mathrm{H}\right), 2.93-2.97$ (m, $\left.1 \mathrm{H}, 9 \mathrm{a}-\mathrm{H}\right), 3.03\left(\mathrm{~d},{ }^{2} J=10.0,1 \mathrm{H}, 1 / 2 \times\right.$ 1- $\mathrm{H}_{2}$ ), 3.20-3.23 (m, $2 \mathrm{H}$, 3a-H and 4-H), 3.53-3.57 (dd, ${ }^{2} J=10.0 \mathrm{~Hz}, J=6.8 \mathrm{~Hz}, 1 \mathrm{H}, 1 / 2 \times 1-$ $\mathrm{H}_{2}$ ), 4.16, 4.79 (2 d, each ${ }^{2} J=14.9,2 \times 1 \mathrm{H}, \mathrm{PhCH}_{2}$ ), 5.02 (br s, $\left.1 \mathrm{H}, 9-\mathrm{H}\right)$, 7.19-7.37 (m, $5 \mathrm{H}$, Ph), 14.7 (br s, $1 \mathrm{H}, \mathrm{COOH}$ ). $\delta_{\mathrm{C}}\left(\mathrm{CDCl}_{3}, 100.6 \mathrm{MHz}\right) 26.8$ (t, C-6), 28.7 (t, C-7), 31.6 (t, C-5), 33.1 (d, C-9a), 36.5 (t, C-8), 39.1 (d, C-4a), 40.1 (d, C-3a), 46.2 (d, C-4), 46.9 (t, $\mathrm{PhCH}_{2}$ ), 52.5 (t, C-1), 117.4 (d, C-9), 127.9, 128.1, 128.8 (3 d, Ph), 134.8 (s, Ph), 144.8 (s, C-8a), 174.5 $(\mathrm{COOH}), 177.0$ (s, C-3). Signal assignments are based on gDQCOSY, gHSQC, gHMBC, and NOESY experiments. 
MS data: $m / z$ (\%): 326 (11), 325 (M+, 51), 281 (44), 280 (14), 279 (29), 278 (13), 147 (17), 146 (43), 145 (14), 131 (13), 120 (11), 118 (11), 105 (14), 92 (12), 91 (100).

2-Benzyl-3-oxo-2,3,3a,4,4a,5,6,7,8,9a-octahydro-1H-benz[f]isoindol-4-carboxamide (12). A solution of $\mathbf{6 c}(1.11 \mathrm{~g}, 4.88 \mathrm{mmol})$ and maleic imide $(0.437 \mathrm{~g}, 4.50 \mathrm{mmol})$ in toluene $(10 \mathrm{~mL})$ was heated in a sealed tube ${ }^{16}$ to $120{ }^{\circ} \mathrm{C}$ for $2 \mathrm{~h}$. Removal of the solvent in vacuo yielded $1.24 \mathrm{~g}$ of a red viscous liquid. The crude product crystallized from a mixture of ethyl acetate, diethyl ether, and tetrahydrofuran (1/1/1, v/v/v) to give 12 (759 mg, 48 \%) as colorless crystals; mp 199$203^{\circ} \mathrm{C}$.

NMR data: $\delta_{\mathrm{H}}\left(\mathrm{CDCl}_{3}, 600 \mathrm{MHz}\right) 1.24-1.27$ (m, $\left.1 \mathrm{H}\right), 1.40-1.44$ (m, $\left.2 \mathrm{H}\right), 1.81-1.87$ (m, $\left.2 \mathrm{H}\right)$, 1.94-2.02 (m, 2 H), 2.19-2.21 (m, 1 H), 2.52 (br s, 1 H, 4a-H), 2.92 (br s, 1 H, 9a-H), 2.97 (d, $J$ = 9.7, $1 \mathrm{H}, 1 / 2 \times 1-\mathrm{H}_{2}$ ), 3.00 (br s, $1 \mathrm{H}, 4-\mathrm{H}$ ), 3.13 (dd, $\left.J=6.3, J=3.5,1 \mathrm{H}, 3 \mathrm{a}-\mathrm{H}\right), 3.46$ (dd, $J=$ 9.5, $\left.J=6.7,1 \mathrm{H}, 1 / 2 \times 1-\mathrm{H}_{2}\right), 4.10,4.79\left(2 \mathrm{~d}\right.$, each $\left.{ }^{2} J=15.1,2 \times 1 \mathrm{H}, \mathrm{PhCH}_{2}\right), 5.01(\mathrm{~s}, 1 \mathrm{H}, 9-\mathrm{H})$, 5.68 (br s, $1 \mathrm{H}, 1 / 2 \times \mathrm{CONH}_{2}$ ), $7.20-7.34\left(\mathrm{~m}, 5 \mathrm{H}, \mathrm{Ph}\right.$ ), 9.78 (br s, $\left.1 \mathrm{H}, 1 / 2 \times \mathrm{CONH}_{2}\right) . \delta_{\mathrm{C}}\left(\mathrm{CDCl}_{3}\right.$, $75.5 \mathrm{MHz}$ ) 26.8, 28.8, 31.0 (3 t), 34.2 (d, C-9a), 36.4 (t, C-8), 39.5 (d, C-4a), 41.0 (d, C-3a), 46.6 (t, $\mathrm{PhCH}_{2}$ ) 46.9 (d, C-4), 51.7 (t, C-1), 118.0 (d, C-9), 127.68, 127.74, 128.7 (3 d, Ph), 135.7, 145.3 (2 s, Ph and C-8a), 175.6, 176.4 (2 s, $\mathrm{CONH}_{2}$ and $\mathrm{CO}$ ). Signal assignments are based on ${ }^{1} \mathrm{H},{ }^{1} \mathrm{H}-\mathrm{COSY90}$ and HETCOR experiments. Anal. Calcd. for $\mathrm{C}_{20} \mathrm{H}_{24} \mathrm{~N}_{2} \mathrm{O}_{2}$ (324.43): C, 74.05; $\mathrm{H}$, 7.46; N, 8.63. Found: C, 73.61; H, 7.47; N, 8.58.

X-Ray crystallography. Data for the crystal structure determinations were collected on a Nonius CAD4-MACH3 diffractometer. The SHELXS-86 software was used to determine the structures, and the refinement was performed using the SHELXL-93 software. The results of the crystal structure determinations and the crystallographic data of $\mathbf{8 , 9}$, and $\mathbf{1 2}$ are summarized in Table $1 .^{17}$ 
Table 1. Crystallographic data and parameters of the crystal structure determinations

\begin{tabular}{|c|c|c|c|}
\hline Compound & 8 & 9 & 12 \\
\hline Empirical formula & $\mathrm{C}_{17} \mathrm{H}_{19} \mathrm{NO}_{3}$ & $\mathrm{C}_{17} \mathrm{H}_{20} \mathrm{~N}_{2} \mathrm{O}_{2}$ & $\mathrm{C}_{20} \mathrm{H}_{24} \mathrm{~N}_{2} \mathrm{O}_{2}$ \\
\hline Formula weight & 285.33 & 284.35 & 324.41 \\
\hline Crystal size (mm) & $0.53 \times 0.47 \times 0.13$ & $0.53 \times 0.43 \times 0.33$ & $0.53 \times 0.30 \times 0.13$ \\
\hline Crystal System & monoclinic & orthorhombic & triclinic \\
\hline Space group & $\mathrm{C} 2 / \mathrm{c}$ & Pca21 & $\mathrm{P}-1$ \\
\hline$a(\AA)$ & $28.762(4)$ & $28.774(7)$ & $6.668(3)$ \\
\hline$b(\AA)$ & $8.8745(13)$ & $8.907(4)$ & $8.699(2)$ \\
\hline$c(\AA)$ & $12.1980(14)$ & $6.089(3)$ & $15.628(2)$ \\
\hline$\alpha\left(^{\circ}\right)$ & 90 & 90 & $83.24(2)$ \\
\hline$\beta\left(^{\circ}\right)$ & $109.272(11)$ & 90 & $79.40(2)$ \\
\hline.$\left.x^{\circ}\right)$ & 90 & 90 & $74.43(3)$ \\
\hline$V\left(\AA^{3}\right)$ & $2939.0(7)$ & $1560.6(10)$ & $856.1(4)$ \\
\hline$Z$ & 8 & 4 & 2 \\
\hline$\rho_{\text {calcd }}\left(\mathrm{g} \mathrm{cm}^{-3}\right)$ & 1.290 & 1.210 & 1.258 \\
\hline$\mu\left(\mathrm{mm}^{-1}\right)$ & 0.088 & 0.080 & 0.082 \\
\hline$F(000)$ & 1216 & 608 & 348 \\
\hline Temperature (K) & $293(2)$ & $293(2)$ & $293(2)$ \\
\hline Wavelength Mo-K ${ }_{\alpha}(\AA)$ & 0.71073 & 0.71073 & 0.71073 \\
\hline$\theta$ range $\left(^{\circ}\right)$ & 2.48 to 23.97 & 2.29 to 23.97 & 2.44 to 23.99 \\
\hline \multirow{3}{*}{ Index ranges } & $-32 \leq h \leq 0$ & $-32 \leq h \leq 0$ & $-7 \leq h \leq 7$ \\
\hline & $0 \leq k \leq 10$ & $0 \leq k \leq 10$ & $-9 \leq k \leq 8$ \\
\hline & $-13 \leq l \leq 13$ & $-6 \leq l \leq 6$ & $-17 \leq l \leq 17$ \\
\hline Reflections collected & 2350 & 2438 & 2886 \\
\hline Independent reflections & 2300 & 2434 & 2683 \\
\hline No. of restraints & 0 & 1 & 0 \\
\hline No. of parameters & 192 & 191 & 217 \\
\hline GooF on $F^{2}$ & 1.093 & 1.130 & 1.106 \\
\hline$R 1[I>2 \sigma(\mathrm{I})]$ & 0.0435 & 0.0478 & 0.0742 \\
\hline$w R 2[I>2 \sigma(\mathrm{I})]$ & 0.0976 & 0.1113 & 0.1697 \\
\hline$R 1$ (all data) & 0.0638 & 0.0702 & 0.1046 \\
\hline$w R 2$ (all data) & 0.1094 & 0.1373 & 0.1885 \\
\hline Resid. electron density $\left(\mathrm{e} \AA^{-3}\right)$ & $0.158 /-0.167$ & $0.140 /-0.136$ & $0.286 /-0.245$ \\
\hline
\end{tabular}




\section{Acknowledgements}

Financial support by the Fonds der Chemischen Industrie is gratefully acknowledged.

\section{References and Notes}

1. Ofial, A. R.; Mayr, H. Angew. Chem. 1997, 109, 145; Angew. Chem., Int. Ed. 1997, 36, 143.

2. Rehn, S.; Ofial, A. R.; Mayr, H. Synthesis 2003, 1790.

3. For a review on allyl amination, see: Johannsen, M.; Jørgensen, K. A. Chem. Rev. 1998, 98, 1689.

4. Ofial, A. R.; Mayr, H. J. Org. Chem. 1996, 61, 5823.

5. (a) Cohen, T.; Onopchenko, A. J. Org. Chem. 1983, 48, 4531. (b) Tidwell, J. H.; Buchwald, S. L. J. Am. Chem. Soc. 1994, 116, 11797.

6. (a) Mellor, J. M.; Wagland, A. M. J. Chem. Soc., Perkin Trans. 1 1989, 997. (b) Mellor, J. M.; Wagland, A. M. Tetrahedron Lett. 1987, 28, 5339.

7. (a) Crisp, G. T.; Gebauer, M. G. J. Org. Chem. 1996, 61, 8425. (b) Gebauer, M. G.; Crisp, G. T.; Tiekink, E. R. T. Z. Kristallogr. 1995, 210, 465.

8. Binder, M.; Tamm, C. Angew. Chem. 1973, 85, 369.

9. Binder, M.; Tamm, C.; Turner, W. B.; Minato, H. J. Chem. Soc., Perkin Trans. 1 1973, 1146. 10. Alvi, K. A.; Nair, B.; Pu, H.; Ursino, R.; Gallo, C.; Mocek, U. J. Org. Chem. 1997, 62, 2148.

11. (a) Kim, B. M.; Guare, J. P. Heterocycles 1995, 41, 403. (b) B. M. Kim, B. M.; Guare, J. P.; Pitzenberger, S. M. Heterocycles 1995, 41, 409.

12. (a) Auerbach, J.; Weinreb, S. M. J. Org. Chem. 1975, 40, 3311. (b) Vedejs, E.; Campbell Jr., J. B., Gadwood, R. C.; Rodgers, J. D.; Spear, K. L.; Watanabe, Y. J. Org. Chem. 1982, 47, 1534.

13. Sauer, J.; Sustmann, R. Angew. Chem. 1980, 92, 773, Angew. Chem., Int. Ed. 1980, 19, 779.

14. Dibenzylamine $(1 \mathrm{mmol})$ and maleic anhydride $(1 \mathrm{mmol})$ were dissolved in $d_{8}$-toluene (2 $\mathrm{mL}$ ) and left at room temperature for $15 \mathrm{~min}$. NMR data of 15: $\delta_{\mathrm{H}}\left(d_{8}\right.$-toluene, $400 \mathrm{MHz}$ ) 4.10, 4.42 (2 s, $2 \times 2$ H, NCH 2$), 6.02$, 6.11 (2 d, each $J=12.5 \mathrm{~Hz}, 2 \times 1 \mathrm{H},-\mathrm{CH}=\mathrm{CH}-)$, 6.867.16 (m, $10 \mathrm{H}, \mathrm{Ph}$ ), 13.40 (br s, $1 \mathrm{H}, \mathrm{COOH}$ ).

15. (a) Tietze, L. F.; Beifuss, U. Angew. Chem. 1993, 105, 137, Angew. Chem., Int. Ed. 1993, 32, 131. (b) Tietze, L. F. Chem. Rev. 1996, 96, 115. (c) Parsons, P. J.; Penkett, C. S.; Shell, A. J. Chem. Rev. 1996, 96, 195. (d) Tietze, L. F. Nachr. Chem. Techn. Lab. 1997, 45, 1181. (e) Tietze, L. F.; Lieb, M. E. Curr. Opin. Chem. Biol. 1998, 2, 363. (f) Tietze, L. F.; Modi, A. Med. Res. Rev. 2000, 20, 304.

16. The reaction was carried out in a pressure tube that was equipped with a magnetic stir bar, sealed with a screw cap and heated in an aluminium block which was standing on the heating platform of a magnetic stirrer. 
17. Crystallographic data (excluding structure factors) for the structures reported in this paper have been deposited with the Cambridge Crystallographic Data Center as supplementary publication no. CCDC-223583 for 8, no. CCDC-223584 for $\mathbf{9}$ and no. CCDC-223585 for 12. Copies of the data can be obtained free of charge on application to CCDC, 12 Union Road, Cambridge CB2 1EZ, UK (e-mail: deposit@ccdc.cam.ac.uk). 